\title{
The use of dehulled grape seed meal in the fattening of rabbits ${ }^{(1)}$
}

\author{
C. CAVANI, A. MAIANI *, M. MANFREDINI *, M. Cristina ZARRI * \\ Istituto di Alimentazione Animale, Università di Bologna \\ Via S. Giacomo, 11, 40126 Bologna, Italia \\ * Istituto di Approvvigionamenti annonari, Mercati e Industrie degli alimenti di origine animale \\ Università di Bologna. Via S. Giacomo, 11, 40126 Bologna, Italia
}

\section{Summary}

The use of dehulled grape seed meal in the fattening of rabbits.

Two trials were carried out in the same environmental conditions in order to study the effects of grape seed meal (G.S.M.), when added (at dosages of 10 and 20 p. 100 in substitution of lucerne meal) to the concentrate feed mixture, on the performance and carcass quality of fattening rabbits.

In the first trial 126 rabbits with a paternal base of Vienna Blue breed were divided into three groups of forty-two subjects each (Control $=$ C ; 10 p. 100 G.S.M. $=$ T1 ; 20 p. 100 G.S.M. = T2). The trial started at the weaning of the animals (about five weeks of age) and ended at a slaughter weight of approx. $2.5 \mathrm{~kg}$.

Daily gain $(30.5 ; 31.4 ; 30.1 \mathrm{~g})$ and feed intake $(128.3 ; 132.6 ; 135.5 \mathrm{~g} / \mathrm{d})$ were similar for $\mathrm{C}$, $T 1$ and $T 2$ respectively, while feed efficiency was reduced when G.S.M. was added at 20 p. 100 level (as feed/gain : $4.50 \mathrm{~T} 2$ vs $4.21 \mathrm{C}$ and $4.22 \mathrm{~T} 1 ; \mathrm{P}<0.05$ ).

In the second trial 90 rabbits were utilized in the same experimental design as the previous trial. Neither, level of G.S.M. influenced all performance parameters. Daily gain was $32.4 ; 32.6$ and $33.3 \mathrm{~g}$; feed intake $133.9 ; 136.1 ; 137.1 \mathrm{~g} / \mathrm{d}$; feed efficiency (feed/gain) $4.13 ; 4.17 ; 4.12$ for $\mathrm{C}, \mathrm{T} 1$ and $\mathrm{T} 2$ respectively.

Neither trial brought to light significant differences between the groups as regards slaughter data (dressing percentages on warm and chilled carcass, cooler shrink, weight of alimentary tract, skin and feet).

The results suggest that G.S.M. may be useful in rabbit feeding in partial substitution of lucerne meal at a level near to $10 \mathrm{p} .100$.

Key words : Grape seed meal, by-product, rabbit fattening.

(1) Research carried out with a grant from C.N.R. for the project I.P.R.A. Subproject 1. Publication $\mathrm{n}^{\circ}$ 1789. This research is part of the programme of research of the Emilia-Romagna Region and was carricd out with the coordination of C.R.P.A. 


\section{Introduction}

As Italy is one of the major wine producers, there is a great quantity of grape seed available each year. A good market exists for the oil which can be extracted from these seeds, using solvents. The by-product of this process, grape seed meal (G.S.M.), has a crude fibre content of around 50 p. 100 and could therefore be used only as a limited part of animal feed. However, the circular sent out by the Italian Ministry of Agriculture and Foresty (M.A.F.) in December 1973 stated that the content of crude fibre must not exceed 35 p. 100 of the dry matter. The grape seeds are thus dehulled and the G.S.M. available on the market therefore has a fibre content that is sometimes considerably lower than 35 p. 100 .

The aim of this trial was to ascertain the effects that the use of grape seed meal, at levels of 10 p. 100 and 20 p. 100 in the diet, could have on the performance of fattening rabbits.

\section{Materials and methods}

Two trials were carried out, at different times, using 216 rabbits, with a paternal base of Vienna Blue breed. In the first trial 126 rabbits were divided in 3 uniform groups each containing 42 animals. Group $C$ (control) received a feed containing no G.S.M., whereas in the group receiving 10 p. 100 G.S.M. this replaced 8.5 p. 100 dehydrated lucerne meal and 1.5 p. 100 soyabean meal; in the group fed a ration with 20 p. 100 G.S.M. this replaced 17 p. 100 dehydrated lucerne meal and 3 p. 100 soyabean meal.

In the second trial, 90 rabbits were divided into 3 groups in the same conditions and using the same experimental design as the first.

Table 1 shows the chemical composition of the G.S.M. and particular attention should be paid to the crude fibre content, which may be as low as half that obtained from grape seed not previously dehulled.

The percentage and chemical composition of the diets are shown in the Tables 2 and 3 respectively.

The feeds were given in pellets and ad libitum.

The trials started when the animals were weaned, at 35 days of age in the first trial and at 30 days in the second, and ended at slaughter of the rabbits at a weight of approximately $2.5 \mathrm{~kg}$. The trials lasted 48 and 51 days respectively.

The rabbits were housed in three-tier caging, with two rabbits in each cage. The animals were weighed individually at intervals of two weeks in order to determine the weight gain and the animals were weighed for the last time at the farm on the day of slaughter; the feed intake refers to that of three subgroups constituted inside each experimental group.

Rabbits which died during the course of the trials underwent necroscopic examination. 
TABle 1

Chemical composition of grape dehulled seed meal.

Composition chimique de tourteau de pépins de raisins.

\begin{tabular}{|c|c|}
\hline$\ldots \ldots \ldots \ldots \ldots \ldots \ldots \ldots$ & 9.03 \\
\hline Crude protein p. $100 \mathrm{~d} . \mathrm{m} . \quad \ldots \ldots \ldots \ldots \ldots$ & 25.98 \\
\hline Ether extract p. 100 d.m. $\ldots \ldots \ldots \ldots \ldots \ldots \ldots$ & 1.24 \\
\hline Crude fibre p. 100 d.m. $\ldots \ldots \ldots \ldots \ldots \ldots \ldots \ldots$ & 22.44 \\
\hline N.D.F. p. 100 d.m. $\ldots \ldots \ldots \ldots \ldots \ldots \ldots \ldots \ldots \ldots \ldots \ldots \ldots \ldots \ldots \ldots$ & 46.51 \\
\hline 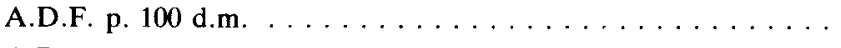 & 38.01 \\
\hline A.D.L. p. 100 d.m. $\ldots \ldots \ldots \ldots \ldots \ldots \ldots \ldots \ldots \ldots \ldots$ & 28.17 \\
\hline 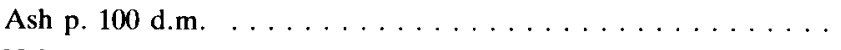 & 6.65 \\
\hline N-free extract p. 100 d.m. $\ldots \ldots \ldots \ldots \ldots \ldots \ldots$ & 43.69 \\
\hline 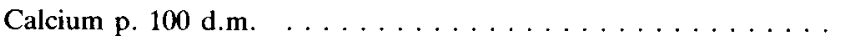 & 1.03 \\
\hline Phosphorus p. 100 d.m. $\ldots \ldots \ldots \ldots \ldots \ldots \ldots$ & .86 \\
\hline Magnesium $\mathbf{g} / \mathbf{K g}$ d.m. $\ldots \ldots \ldots \ldots \ldots \ldots$ & 2.94 \\
\hline Potassium $\mathrm{g} / \mathrm{Kg}$ d.m. $\ldots \ldots \ldots \ldots \ldots \ldots \ldots$ & 10.49 \\
\hline Sodium $\mathrm{g} / \mathrm{Kg} \mathbf{d} \mathbf{m} . \quad \ldots \ldots \ldots \ldots \ldots \ldots \ldots \ldots$ & .95 \\
\hline Iron $\mathbf{m g} / \mathrm{Kg}$ d.m. $\quad \ldots \ldots \ldots \ldots \ldots \ldots \ldots \ldots \ldots \ldots \ldots \ldots \ldots \ldots \ldots$ & 11.95 \\
\hline Zinc $\mathbf{m g} / \mathbf{K g}$ d.m. $\ldots \ldots \ldots \ldots \ldots \ldots \ldots \ldots$ & 42.53 \\
\hline 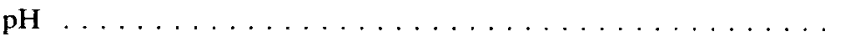 & 4.62 \\
\hline
\end{tabular}

TABLE 2

Percent composition of experimental diets.

Composition percentuelle des aliments expérimentaux.

\begin{tabular}{|c|c|c|c|}
\hline Ingredients & Control & 10 p. 100 G.S.M. & 20 p. 100 G.S.M \\
\hline Grape dehulled seed meal $\ldots \ldots \ldots \ldots$ & - & 10.0 & 20.0 \\
\hline Dehydrated lucerne meal $\ldots \ldots \ldots \ldots$ & 21.0 & 12.5 & 4.0 \\
\hline Barley meal $\ldots \ldots \ldots \ldots \ldots$ & 20.3 & 20.0 & 20.0 \\
\hline Mixed hay meal $\ldots \ldots \ldots \ldots \ldots \ldots$ & 14.0 & 14.0 & 14.0 \\
\hline Soyabean meal, solv. extr., 44 p. 100 C.P. . . & 13.0 & 11.5 & 10.0 \\
\hline Wheat bran $\ldots \ldots \ldots \ldots \ldots$ & 8.2 & 8.2 & 8.2 \\
\hline Maize meal & 7.8 & 7.8 & 7.8 \\
\hline$\ldots \ldots \ldots \ldots \ldots$ & 4.8 & 4.8 & 4.8 \\
\hline Sunflower meal, solv. extr., 42 p. 100 C.P. . . & 4.2 & 4.2 & 4.2 \\
\hline Sugar cane mol sses $\ldots \ldots \ldots \ldots \ldots$ & 2.1 & 2.1 & 2.1 \\
\hline Dicalcium phrsphate $\ldots \ldots \ldots \ldots$ & 1.7 & 1.7 & 1.7 \\
\hline Calcium carbonate $\ldots \ldots \ldots \ldots \ldots$ &.- & 0.3 & 0.3 \\
\hline Sodium chloride $\ldots \ldots \ldots \ldots \ldots$ & 0.2 & 0.2 & 0.2 \\
\hline Lignin sulphonate $\ldots \ldots \ldots \ldots \ldots$ & 1.9 & 1.9 & 1.9 \\
\hline Mineral vitamin premix $\ldots \ldots \ldots \ldots$ & 0.8 & 0.8 & 0.8 \\
\hline
\end{tabular}


TABLE 3

Chemical composition of experimental diets (mean \pm standard error). Composition chimique des aliments expérimentaux (moyenne \pm erreur-type).

\begin{tabular}{|c|c|c|c|}
\hline $\begin{array}{ll}\text { Parameters } & \text { Groups }\end{array}$ & Control & 10 p. 100 G.S.M. & 20 p. 100 G.S.M \\
\hline Number of analysis & 5 & 5 & 5 \\
\hline Moisture p. $100 \ldots$ & $9.50 \pm 0.20$ & $9.26 \pm 0.24$ & $9.08 \pm 0.24$ \\
\hline Crude protein p. 100 d.m. . . . . . & $17.14 \pm 0.04$ & $17.40 \pm 0.14$ & $17.89 \pm 0.11$ \\
\hline Ether extract p. 100 d.m. . . . . . & $3.31 \pm 0.30$ & $3.26 \pm 0.48$ & $2.76 \pm 0.27$ \\
\hline Crude fibre p. 100 d.m. . . . . . . & $16.07 \pm 0.40$ & $16.75 \pm 0.40$ & $15.89 \pm 0.30$ \\
\hline 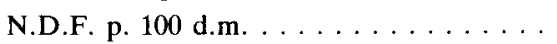 & $30.29 \pm 0.06$ & $29.81 \pm 0.98$ & $30.26 \pm 0.59$ \\
\hline A.D.F. p. 100 d.m. $\ldots \ldots \ldots$ & $20.06 \pm 0.62$ & $20.30 \pm 0.29$ & $21.72 \pm 0.36$ \\
\hline A.D.L. p. $100 \mathrm{~d} . \mathrm{m} . \quad \ldots \ldots \ldots$ & $4.97 \pm 0.03$ & $7.25 \pm 0.29$ & $9.64 \pm 0.52$ \\
\hline Ash p. 100 d.m. . . . . . . & $8.03 \pm 0.03$ & $7.89 \pm 0.03$ & $7.59 \pm 0.14$ \\
\hline $\mathrm{N}$ - free extract p. 100 d.m. . . & $55.46 \pm 0.14$ & $54.70 \pm 0.13$ & $55.87 \pm 0.20$ \\
\hline Calcium p. 100 d.m. . . . . . . . . & $1.38 \pm 0.04$ & $1.45 \pm 0.10$ & $1.26 \pm 0.07$ \\
\hline Phosphorus p. 100 d.m. . . . . . . . & $0.67 \pm 0.19$ & $0.76 \pm 0.01$ & $0.82 \pm 0.00$ \\
\hline $\mathrm{pH} \ldots \ldots \ldots \ldots \ldots \ldots \ldots$ & 5.98 & 5.78 & 5.61 \\
\hline Digestible Energy ${ }^{(1)}$ M.J./kg d.m. . . . & 11.22 & - & - \\
\hline
\end{tabular}

(1) According to Parigi Bini R. and Dalle Rive V. (1977).

The live weight, weight of the skin and feet as well as that of the alimentary tract and of the warm and chilled carcass were all measured at slaughter.

Refrigeration took place in ventilated refrigeration cells at a temperature of $4{ }^{\circ} \mathrm{C}$ for $14 \mathrm{hrs}$.

Sixty carcasses ( 20 per group) in the first trial, and 30 in the second (10 per group) were chosen at random and frozen at $-18{ }^{\circ} \mathrm{C}$ for dissection. A sample cut was obtained of the hind region (pelvis and thighs) as indicated by Rouvier (1970). The percentages of muscle and bone tissues were thus calculated; the fat was present in very small quantities and was difficult to separate : it was therefore considered together with the muscle.

Data were analyzed using analysis of variance. Where significant $F$ values for treatment effects occurred, means were evaluated by DuNCAN's multiple range test (STEEL \& TORRY, 1960).

\section{Results and discussion}

\section{A. Daily gain, feed intake and feed efficiency}

The data obtained are reported in Table 4 . The daily weight gain in the first trial did not differ statistically between the three groups. However, the feed intake tended 


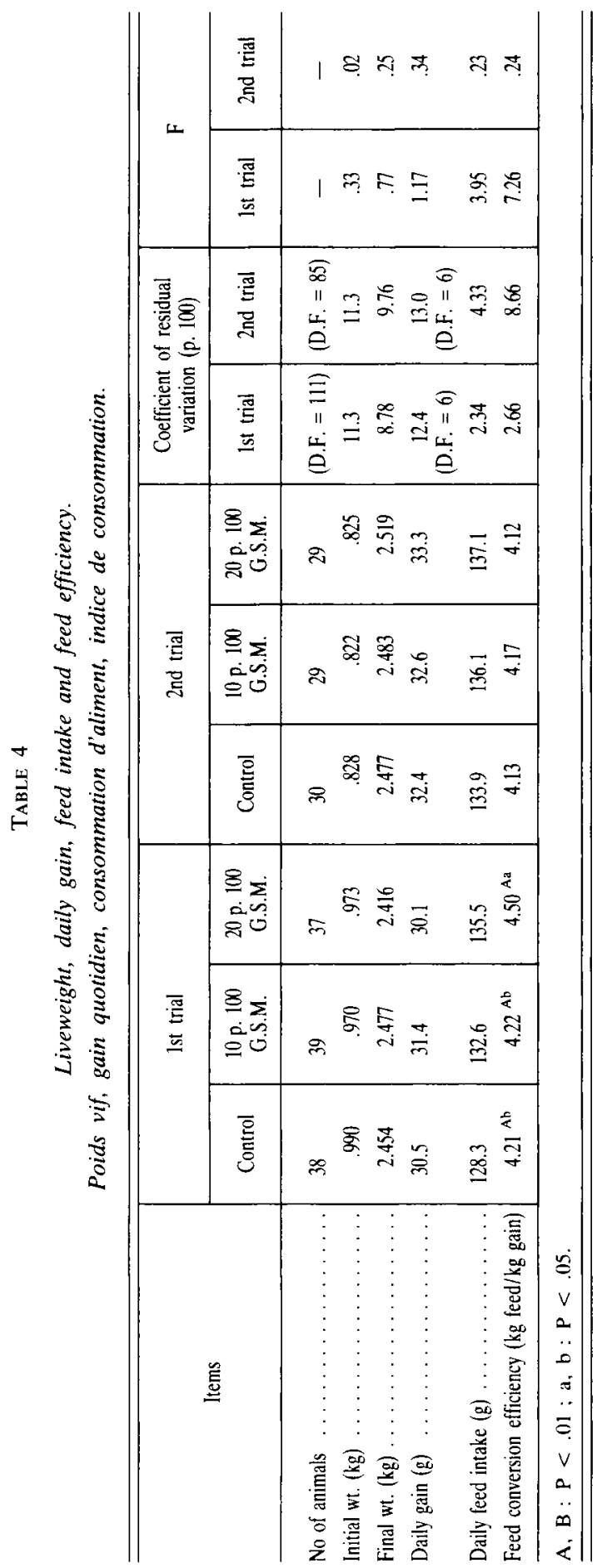




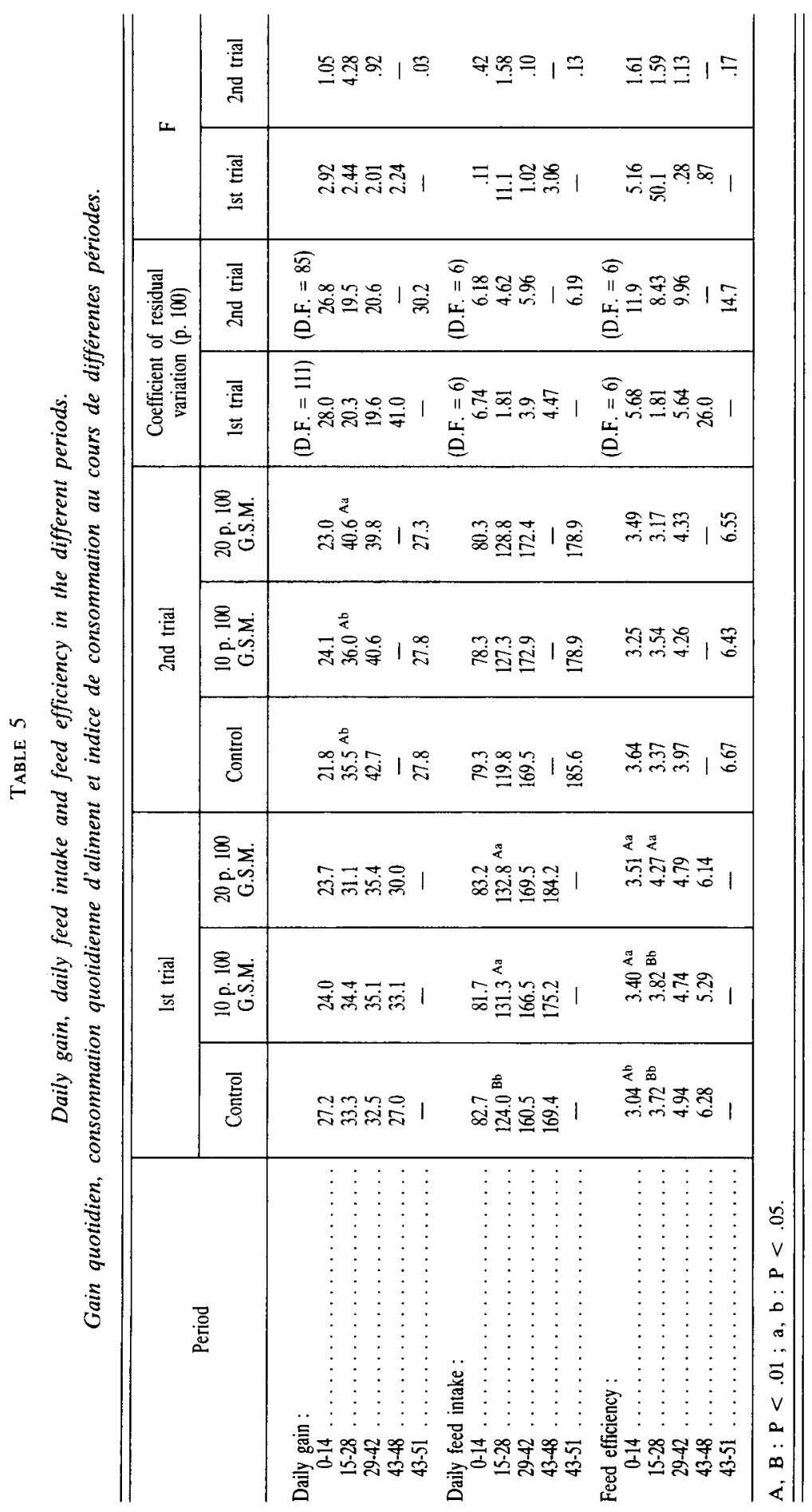


to increase with the addition of G.S.M. (128.3 vs 132.6 vs $135.5 \mathrm{~g} / \mathrm{d})$. The feed to gain ratio was higher in the group with 20 p. 100 G.S.M., while it was practically identical in the other two groups; the difference is significant $(\mathrm{P}<.05)$.

As may be seen from Table 5, which reports the performances in the different periods, the highest feed to gain ratio found in the first trial in the group receiving 20 p. 100 G.S.M. is due to the considerably reduced feed efficiency of the animals in the early stages of fattening (0-28 days).

The data of the second trial (Table 4) only partly agree with those of the first. This trial also showed a trend towards higher feed intake in the treated groups. The daily weight gain was higher, though not significantly so, in the group with $20 \mathrm{p} .100$ G.S.M., in contrast with the result of the first experiment. The feed efficiency was therefore very similar in all three groups.

Table 5 shows the daily weight gain, feed intake and feed efficiency recorded at intervals of two weeks (with the exception of the period before slaughter). With the exception of the statistically significant differences regarding the feed efficiency, discussed above, it may be noted that the performance parameters considered were very similar in all three groups of both trials.

The relatively high feed conversion indices may be partly explained by the high initial weight of the kits and by the type of housing, which had no environment control equipment. It should be noted that the feed efficiency was worst in the finishing phase (last week) for all the experimental groups. This trend may be useful in establishing the most suitable age and weight for slaughter.

From an overall view of the results it may be concluded that G.S.M. could be used in the fattening of rabbits with good results and in amounts that are economically viable (around 10 p. 100).

Unfortunately in the literature consulted, no trial using similar G.S.M. to that used in our trials with rabbits was found. In experiments carried out by AlicATA et al. (1987) and at I.T.C.F. (1982) using whole grape seed (at levels from 10 to 30 p. 100) in the fattening of rabbits the results were favourable as regards daily weight gain and feed efficiency.

\section{B. Health and mortality rate}

The health of the rabbits was good throughout both the trials. Daily observation of the animals did not reveal any apparent differences in the health of the animals in the three groups. The mortality rate was $9.5 ; 7.1$ and 11.9 p. 100 respectively in groups $C$, 10 p. 100 G.S.M. and 20 p. 100 G.S.M. in the first trial and $0 ; 3.3$ and 3.3 p. 100 in the second one. Apart from the uniformity of the values found, the necroscopic examination did not show any link between the cause of death and the treatment.

It may therefore be concluded that G.S.M., at the levels used, does not affect the state of health of fattening rabbits.

\section{Slaughter data and carcass dissection}

The slaughter data and carcass dissection, reported in Tables 6 and 7, show no significant differences between the groups of either trial. 


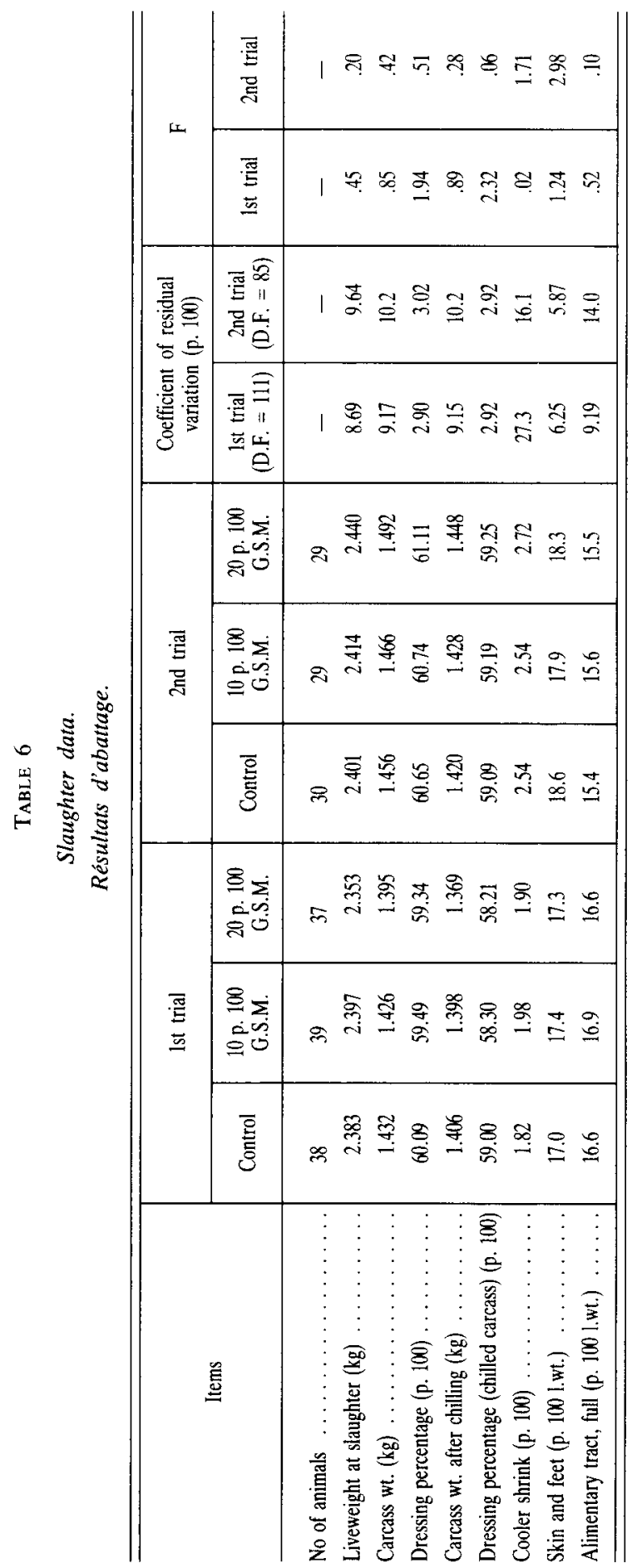




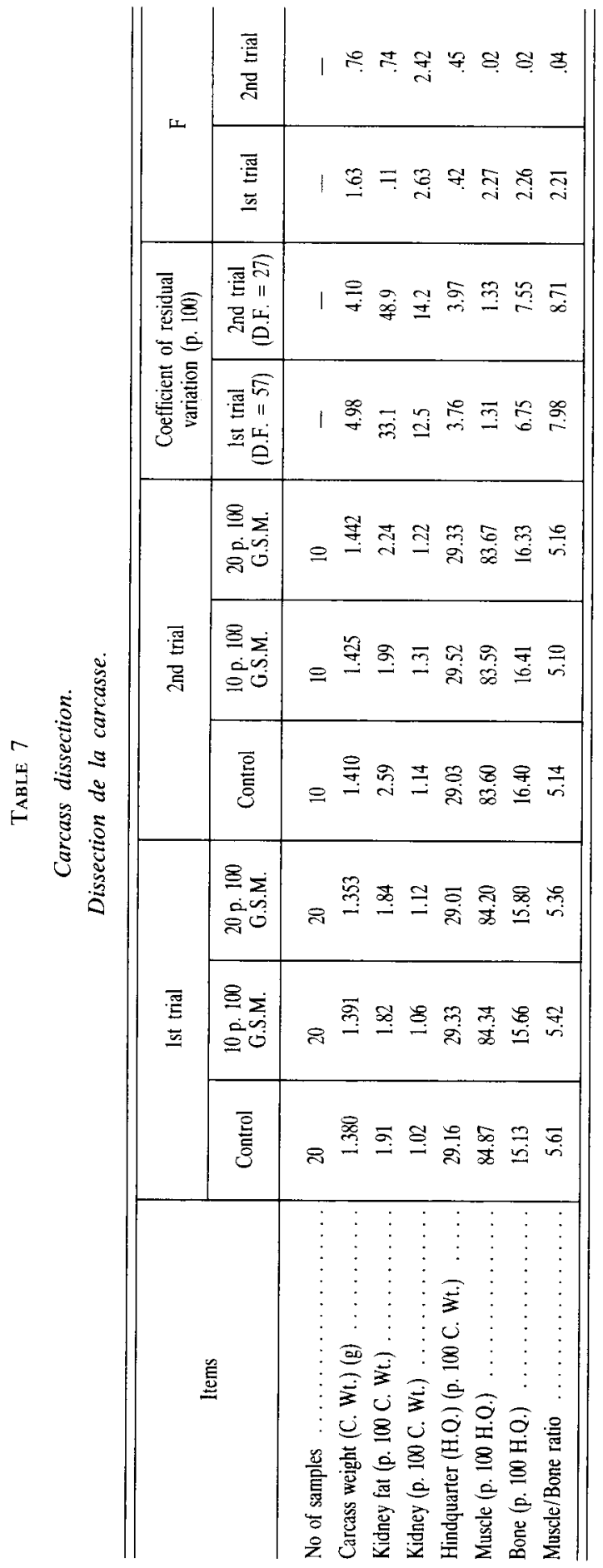


As already stated, the weight of the separable fat of the hindquarters was not measured at dissection, and thus the percentage of muscle and the muscle/bone ratio is slightly overestimated. It may however be observed that the percentage of fat in the hindquarters is very low, approx. $1 \mathrm{p} .100$ in rabbits with a live weight of $2.5 \mathrm{~kg}$, as demonstrated by the work of VAREwick \& BouQueT (1982). An overall view of these results thus leads to the conclusion that the G.S.M. influenced neither the dressing percentage nor the carcass composition.

\section{Economic considerations}

The use of G.S.M. in the feeding of rabbits is advantageous as the addition of this by-product leads to a decrease in the cost of the feed due to the replacement of a certain percentage of the traditional components.

As stated previously, in these trials 10 parts G.S.M. replaced 8.5 parts dehydrated lucerne meal and 1.5 parts soyabean meal. The calculation was made using the average prices (April 1988) of the raw materials replaced (dehydrated lucerne meal and soyabean meal 26.000 and 37.500 Italian Lires $/ 100 \mathrm{~kg}$ respectively) and considering the price of G.S.M. to $\mathrm{b}: 13,500$ Italian Lires $/ 100 \mathrm{~kg}$, the difference was 4.9 and $9.8 \mathrm{p}: 100$ between the groups containing 10 and 20 p. 100 G.S.M. respectively and the control group.

On the basis of the results of the trials, without considering other factors apart from the cost of the feed components, that may affect the feed costs, it may be calculated that an addition of 10 p. 100 G.S.M. leads to a saving per $\mathrm{kg}$ of weight gain of around 4-5 p. 100 . No calculation was made for the groups containing 20 p. 100 G.S.M. as the two trials did not give comparable results.

\section{Conclusions}

The results obtained showed that the use of G.S.M. to partially replace dehydrated lucerne meal and soyabean meal in the feeding of fattening rabbits did not negatively affect the well-being of the animals or the carcass quality. As far as the performance is concerned, it may be suggested that an addition of 10 p. 100 G.S.M. is the level that gives the most reliable results.

Reçu en octobre 1987.

Accepté en avril 1988. 


\section{Résumé}

\section{Utilisation de tourteau de pépins de raisins décortiqués pour l'engraissement des lapins}

Deux essais ont été conduits, dans les mêmes conditions expérimentales, afin d'étudier les effets du tourteau de pépins de raisins (T.P.R.), ajouté (à taux de 10 et $20 \mathrm{p} .100$ en remplacement de farine de luzerne) au concentré, sur les performances et sur la qualité de carcasse des lapins.

Dans le premier essai, 126 lapereaux de souche paternelle de la race Bleu de Vienne ont été divisés en trois groupes, chacun contenant 42 sujets (Témoin $=T ; 10$ p. 100 T.P.R. $=T$ T ; 20 p. 100 T.P.R. = T2)

On a commencé l'essai au sevrage des animaux (environ cinq semaines d'âge) et terminé au poids d'abattage d'environ $2,5 \mathrm{~kg}$.

Le gain de poids quotidien $(30,5 ; 31,4 ; 30,1 \mathrm{~g})$ et la consommation d'aliment $(128,3 ; 132,6$; $135,5 \mathrm{~g} / \mathrm{d}$ ) étaient semblables pour $\mathrm{T}, \mathrm{T} 1$ et $\mathrm{T} 2$ respectivement, tandis que l'indice de consommation était plus élevé quand il y avait une addition de TPR au taux de 20 p. 100 (aliment/gain de poids $=4,50 \mathrm{~T} 2$ vs 4,21 $\mathrm{T}$ et 4,22 $\mathrm{T} 1 ; \mathrm{P}<0,05)$.

Dans le second essai, 90 lapereaux ont été utilisés avec le même schéma expérimental que celui du premier essai. Les deux régimes avec T.P.R. n'ont pas influencé les principaux paramètres de performance. Les gains de poids quotidiens étaient de 32,$4 ; 32,6$ et $33,3 \mathrm{~g}$; les consommations d'aliment de 133,9;136,1;137,1 $\mathrm{g} / \mathrm{d}$; et les indices de consommation (aliment/gain) de 4,13; 4,$17 ; 4,12$ pour $\mathrm{T}, \mathrm{T} 1$ et $\mathrm{T} 2$ respectivement.

Aucune différence significative n'a été notée entre les groupes au niveau des rendements à l'abattage à chaud et à froid, diminution de poids après réfrigération, poids du tube digestif, peau et pattes. Les résultats indiquent que le T.P.R. pourrait être utilisé dans l'alimentation des lapins au taux d'environ 10 p. 100.

Mots clés: Tourteau de pépins de raisin, sous-produit, engraissement du lapin.

\section{References}

Alicata M.L., Bonanno A., Giaccone P., Leto G., 1987. Impiego del vinacciolo integrale nell'alimentazione del coniglio da carne. Zoot. Nutr. Anim., 13, 195 (Abstr.).

I.T.C.F., 1982. Lupin, féverole, pépins de raisin pour lapins à l'engraissement. Cuniculture, 48 , 284-287.

M.A.F., 1973. Circular Letter n. 1870 (15.12.1973).

Parigi Bini R., Dalle Rive V., 1977. Metodi di stima del valore nutritivo dei mangimi concentrati per conigli in accrescimento. Coniglicoltura, 14, 33-40.

Rouvier R., 1970. Variabilité génétique du rendement à l'abattage et de la composition anatomique de lapins de trois races. Ann. Génét. Sél. Anim., 2, 325-346.

Steel R.G.D., Torrie J.T., 1960. Principles and Procedures of Statistics. McGraw-Hill, New York U.S.A.

Varewick H., Bovquet Y., 1982. Relations entre la composition tissulaire de la carcasse de lapins de boucherie et celle des principaux morceaux. Ann. Zootech., 31, 257-268. 